Please refer to the definitive version of this article when citing:

Kantenbacher, J. Hanna, P., Cohen, S., Miller, G. \& Scarles, C. (2018). Public attitudes about climate policy options for aviation. Environmental Science \& Policy, 81, 46-53.

\title{
Public attitudes about climate policy options for aviation
}

\begin{abstract}
The current trend of increasing demand for air travel runs contrary to climate-related sustainability goals. The absence of behavioural and near-term technological solutions to aviation's environmental impacts underscores the importance of policy levers as a means of curbing carbon emissions. Where past work has used qualitative methods to sketch public opinion of environmental aviation policies, this work uses data drawn from a survey of 2066 British adults to make a quantitative assessment of the acceptability of a broad range of aviation climate policy options. The findings indicate that there is significant support across demographic groups for a large number of policies, particularly those that place financial or regulatory burdens on industry rather than on individuals directly. Support for aviation policies strengthens with proenvironmental attitudes and is weaker among people who are aeromobile. Though self-interested considerations appeared to dominate policy option preferences, concern for fairness may also shape policy acceptability. Overall, this paper provides to policymakers a quantitative evidence base of what types of policies for addressing aviation climate emissions are most publically palatable.

Highlights

- British adults were surveyed about support for climate-based aviation policies

- Many proposed policies measures received positive overall support

- Policies with the least negative or most positive effect on consumers rated highest

- Pro-environmental beliefs and aeromobile behaviour best predicted support levels

- A preference for fairness may affect support levels for aviation policies
\end{abstract}

Keywords: aviation, emissions, policy support, public attitudes, United Kingdom

\section{Introduction}

Aviation has undergone considerable growth in recent decades, with continued substantial growth forecasted (Peeters et al. 2016). The International Energy Agency (2009) expects air travel to nearly quadruple between 2005 and 2050, as it is anticipated to expand at 3.5\% per year. The present 'steep growth path' is largely attributed to the advent of the low-cost business model and the rapid development of the tourism industry in emerging world regions, particularly Asia (McManners 2016: 87). Although aviation currently accounts for $2-3 \%$ of global $\mathrm{CO}_{2}$ emissions (Owen et al. 2010), its contribution is forecast to rise to $22 \%$ by 2050 , assuming the sector's mitigation efforts continue to lag behind that of others and that policies to combat its climate impact are further postponed (Cames et al. 2015).

Though aviation emissions are rising rapidly at a global level, there is an absence of international policy measures on the horizon to address the situation (Peeters et al. 2016). Whilst international aviation is not covered under the emissions reduction path set out by the 2015 Paris Agreement (Becken and Mackey 2017) - the majority of its emissions are in international air space and thus 
not attributable to particular nations - the UN International Civil Aviation Organization has recently approved targets for emissions reductions from this source. Greater policy coverage exists for domestic aviation, the emissions from which being typically included in national GHG inventories and reduction targets (Bows and Anderson 2007). As domestic initiatives will conceivably remain the primary source of climate policies directed at the aviation sector, attention to the factors, including public sentiment, affecting the nature and scope of these policies is warranted.

\section{Background}

Aviation has been identified as the most difficult sector for implementing sustainability in policy formulation, arguably due to the idea that it represents "a prime example of a direct clash between environmental and economic policy" (McManners 2016: 87) and because of the lack of sustainable alternatives for people to transition into. There has been little appetite among policymakers to control aviation emissions due to concerns about the economic consequences this would have, as aviation is perceived as a vital enabler of the global economy (McManners 2016).

Furthermore, this international environmental problem will not be solved by technology alone. Although airlines have become considerably more fuel efficient since the 1960s, prospects for future efficiency gains are low and emissions growth has outpaced efficiency gains for decades due to the continuous expansion of passenger volumes (Peeters et al. 2016). Though proponents of biofuels, for instance, maintain that technological innovations will lead to a low-carbon future for aviation (cf. Filimonau and Högström 2017), "silver-bullet" technological solutions have been exposed as 'myths' that are stalling progress in aviation climate policy (Peeters et al. 2016).

Voluntary behavioural changes in passenger demand will also not be capable of solving the issue single-handedly. Such behavioural changes would for example include fewer flights, a reduction in distances travelled, longer lengths of stay, and choosing more sustainable transport modes (e.g., rail) (Kroesen 2013). Though work has focused less on how to change flying behaviour than on more routine transport modes, particularly car travel, changing the former will arguably be harder and more important to change than car travel behaviour (Capstick et al. 2014). Despite evidence that publics are aware of air travel's climate impact (Hares et al. 2010), and express concern about it (Higham and Cohen 2011), passenger demand will not subside as a result of public concern over aviation's climate impact (Cohen et al. 2016). Shaw and Thomas (2006) observe that air travel is a classic example of the "tragedy of the commons", that is, that reducing personal benefits for the greater good is perceived as useless unless others do the same. A similar problem is expressed through Higham and colleague's discussion of the "flyers' dilemma", defined as "the tension that exists between the perceived personal benefits of deeply embedded air travel practices and the collective climate change consequences of such practices" (2014: 462). Higham et al. (2014) note a lack of a sense of individual responsibility for the climate impacts of flying among the study's British interviewees, who viewed individual reductions in flying as an "exercise in futility".

Numerous studies have shown that consumers are largely unwilling to voluntarily change their air travel behaviour due to environmental concern (e.g., Hares et al. 2010; Miller et al. 2010), a conundrum now widely explained as an exemplar of the attitude-behaviour gap that can often inhibit pro-environmental behaviour (Cohen et al. 2016; Kroesen 2013). Voluntary behaviour change approaches in their own right have been heavily critiqued, wherein they are viewed as trapped within a neoliberal framing (Hanna et al. 2017), which devolves responsibility to consumers and the market, thereby absolving governments of the need to stimulate structural change through harder regulation (Barr et al. 2011). 
Recognition of the limitations of both technological innovation and voluntary behaviour change in mitigating aviation's climate impact has led to an increasing focus on policy responses to the issue (Gössling et al. 2016). Various policy levers have been examined and critiqued, mainly relying on qualitative methods such as individual in-depth interviews and focus groups. (For an exception employing choice experiments see Araghi et al. [2016].) For instance, Ryley et al. (2010) examine through focus groups UK public attitudes towards current and potential future taxes on aviation and find support to be greatest for any additional tax revenue to be spent on cross-subsidising UK surface transport and developing aircraft technology. However, their respondents on the whole felt that responsibility for aviation emissions should sit with industry and policy-makers, rather than the public. Using in-depth interviews across four nations, Higham et al. (2016) study public receptiveness to voluntary measures, such as carbon offsetting, industry initiatives and types of government regulation that can be aimed at reducing the impact of aviation emissions. Higham et al. (2016: 346) identify a range of soft bottom-up (e.g., social marketing and nudge) and hard policy responses (e.g., rationing, pricing and taxation) and conclude that in the 'political minefield' of regulating air travel, ' $[\mathrm{w}]$ hat form such measures take, and how they can be made more acceptable in different societies, are critical questions.'

The present paper consequently takes as its departure point the need to assess pubic support towards a spectrum of hard and soft aviation climate policy measures. Taking the UK as its national focus, the paper's aim is therefore to provide a quantitative assessment of the acceptability of a broad range of aviation climate policy options to the British public. The paper's empirical findings are from a large-scale online panel survey $(n=2066)$, based on a random sample, specifically commissioned for this research. Quantitative data has been gathered on the extent to which individuals are supportive of a series of proposed policy initiatives and the extent to which demographic factors, environmental attitudes and existing travel behaviours influence the palatability of such policy initiatives. The findings can be generalised to the British public and thus provide a rigorous and original evidence base of public opinion, informing policy debates about the palatability of options for tackling the problem of aviation's climate impact through regulation.

\section{Methods}

\subsection{Survey instrument}

A quantitative online panel survey approach was adopted to facilitate this study's data collection. To measure the environmental beliefs and attitudes of the participants in this study, the panel survey drew on items used by the UK's Department for Environment, Food \& Rural Affairs (DEFRA) in their 2007 and 2009 research reports on public attitudes and behaviour towards the environment. These measures have been validated by DEFRA (2007, 2009) and were felt to sufficiently capture the elements of environmental attitudes of interest for this research. This study's survey included items that measure the participants' beliefs and degree of concern about climate change and general environmental impact (13 items) and the extent to which they feel certain institutions (e.g., national governments, charities) are responsible for tackling climate change (7 items). To measure public support for policy initiatives related to reducing the climate impact of air transport, 14 items were developed based on a range of policy initiatives related to holidays and flying that previous studies have proposed as ways to meet national and international environmental targets (e.g., Higham et al. 2014; Higham et al. 2016; Kroesen 2013). Each item was measured on a 5-point Likert-type scale. These policy propositions represented a range of policy approaches, including taxation, subsidisation, various nudge techniques, and aviation industry regulation (see Appendix A). 
To examine the variance in policy support across different groups, several standard sociodemographic variables, such as gender, were measured. This study opted for a 5-point measurement of education which splits in to the following categories: 1) primary education or less; 2) secondary education; 3) post-secondary education below degree level; 4) first degree or equivalent; 5) higher degree or equivalent. In addition, to remain open to the diverse range of employment in the UK, employment status was measured as a string variable and later categorised, while age and personal income were open measurements.

Finally, respondents were asked to characterise their flying behaviour using four items. Two items asked respondents to record their typical annual count of long- and short-haul flights for both work and non-work purposes. An additional two items asked how many holidays, within the UK and abroad, the respondent goes on in a typical year.

\subsection{Survey distribution}

A well-established third-party organisation was commissioned to distribute the online panel survey and to ensure a random sample was obtained. This organisation is a leading market research firm in the UK and is supported by a range of leading UK higher education institutions. The panel survey was administered online during a two-week period in November 2015. The third-party organisation ensured a sample size that accounted for the minimum representation of individuals that have used air transport for at least one of their holidays in the past year (minimum of 384 required for this group based on UK statistics approximating 33 million in UK flying, minimum 95\% confidence level and 5\% confidence interval). To compare this population with those who do not fly and those who fly frequently, 2000 respondents were targeted to ensure the minimum sample requirements were met across all three groups of interest (with the non-flyers requiring the same minimum as flyers and the frequent flyers unknown as the total population of this group is unknown).

\subsection{Data analysis}

Where appropriate, items designed to measure environmental beliefs and policy support were reverse coded so that a response value of 1 represents the least pro-environmental extreme of the response range, making a response of 5 the most pro-environmental. Seven of the 13 environmental beliefs items were selected to create a pro-environmental beliefs (PEB) construct, which indicates the strength of a respondent's pro-environmental orientation. ${ }^{1}$ The PEB construct created from these 7 items had a Cronbach's alpha value of 0.79 , above the threshold of 0.7 that conventionally marks construct validity (Field 2013). Similarly, support scores for the 14 policy options were averaged to create a composite policy support scale. This "average policy support" composite had a Cronbach's alpha value of 0.90 , suggesting strong internal consistency.

Data from questions concerning the average number of work and non-work flights taken per year were used to create a flyer dummy variable: if the respondent typically takes at least one return flight

\footnotetext{
1 The six environmental beliefs statements that were excluded from the creation of the pro-environmental beliefs construct were: 1) "I don't believe that my behaviour and everyday lifestyle contribute to climate change"; 2) "Climate change is beyond control - it's too late to do anything about it"; 3) "People in the UK will be affected by climate change in the next 200 years"; 4) "I believe my everyday practices (e.g., recycling, reusing, LED/low-energy lighting) counteract any impacts from my holidays;"; 5) "It's not worth me doing things to help the environment if others don't do the same"; 6) "It's not worth Britain trying to combat climate change, because other countries will just cancel out what we do." Items were excluded from the construct if agreeing or disagreeing with the statement could reasonably be based on a pro-environmental orientation. For example, someone might disagree with the statement that "climate change is beyond control" because they discount the magnitude of climate change or because they are optimistic about potential solutions despite strong concern about climate change.
} 
of any description per year, they were labelled as flyers. An overall policy support variable was created by averaging the level of support across the 14 specific policy items in the survey. The string variable for employment status was coded to fit within four general categories: employed, unemployed, student, and retired. Similarly, data on educational attainment was recoded into a binary variable marking whether the respondent had completed a first degree. To limit the impact of the potential inaccuracies associated with the self-reported income data, income data were transformed from a continuous variable into a series of dummy variables corresponding to the 2013-14 personal income quintiles reported by the UK Revenue and Customs agency (HMRC 2017).

Regression models were used to investigate the factors that affect support for pro-environmental aviation policies in general and for specific forms of pro-environmental policies. Parametric regressions were created despite the non-normality (as indicated by Shapiro-Wilk tests) of key variables. Large sample sizes mean that parametric tests become robust in the face of normality assumptions (Lumley et al. 2002), and the sample size of this research is well in excess of the definition of "large" established in previous work. Further, parametric tests can be used with Likert-type data without sacrificing power (de Winter and Dodou 2010). For all statistical analyses, $\mathrm{R}$ (version 3.1.1) was used.

\section{Results}

\subsection{Survey sample characteristics}

A total of 2068 surveys were returned. Two responses were dropped because the self-reported income value $(f, 0)$ did not reasonably fit the respondent's occupation, reducing the final sample size to 2066. The characteristics of the sample are given in Table 1.

Table 1. Description of survey population.

\begin{tabular}{|c|c|}
\hline $\begin{array}{l}\text { Socio-demographic } \\
\text { variable }\end{array}$ & Sample values \\
\hline Age & $\begin{array}{l}\text { Mean: } 46 \text { years } \\
\text { Range: } 18-85 \text { years }\end{array}$ \\
\hline Gender & $\begin{array}{l}\text { Female: } 56 \% \\
\text { Male: } 44 \%\end{array}$ \\
\hline Personal income & $\begin{array}{l}\text { First (lowest) quintile: } 37 \% \\
\text { Second quintile: } 15 \% \\
\text { Third quintile: } 20 \% \\
\text { Fourth quintile: } 17 \% \\
\text { Fifth (highest) quintile: } 11 \% \\
\end{array}$ \\
\hline Flying behaviour & $\begin{array}{l}\text { Flyers: } 66 \% \\
\text { Non-flyers: } 34 \%\end{array}$ \\
\hline
\end{tabular}

\subsection{Levels of support for policy options}

Table 2 shows the overall levels of support for the fourteen policy options, weighted according to UK population-wide income and age statistics to account for the socio-economic nonrepresentativeness of the sample. The average level of support (3.3) across the five-point scale (1 $=$ 'strongly reject', $5=$ 'strongly support') is slightly above the neutral midpoint. Nine of the 14 policies had an average level of support that was significantly higher than neutral whilst three policies had an average level of support that was significantly below neutral $(p s<0.05)$.

Table 2. Mean support values for surveyed policy options.

\begin{tabular}{|l|l|}
\hline Policy measure & $\begin{array}{l}\text { Sample } \\
\text { average }\end{array}$ \\
\hline Develop public transport & 4.0 \\
\hline
\end{tabular}




\begin{tabular}{|l|l|}
\hline Regulate aviation industry & 3.9 \\
\hline Sanctions on international travel by government officials & 3.8 \\
\hline Financial incentives for UK-based holidays & 3.7 \\
\hline Provide information about environmental impacts & 3.6 \\
\hline Introduce cross-subsidization & 3.5 \\
\hline Mandatory carbon offsetting for flights & 3.4 \\
\hline Public recognition of pro-environmental behaviour & 3.1 \\
\hline Frequent flyer tax & 3.1 \\
\hline Personal carbon allowance scheme & 3.0 \\
\hline Increase aviation tax & 3.0 \\
\hline Allow for trading of personal carbon allowance & 2.9 \\
\hline Limited number of flights per year & 2.7 \\
\hline Sanctions on cruises and all-inclusives & 2.6 \\
\hline
\end{tabular}

Table 3 shows participants' mean rating of the responsibility that various organisational types have for tackling the issue of climate change. All seven institutions asked about in the survey received an average score above 3 on the 5 -point scale ( $1=$ 'not at all responsible', $5=$ 'very responsible').

Table 3. Mean rating of responsibility

for addressing climate change

\begin{tabular}{|l|c|}
\hline Organisation type & $\begin{array}{c}\text { Sample } \\
\text { average }\end{array}$ \\
\hline International government & 4.4 \\
\hline Industry & 4.4 \\
\hline National government & 4.3 \\
\hline General public & 4.2 \\
\hline Local government & 3.9 \\
\hline Non-governmental organisations & 3.6 \\
\hline Charities & 3.3 \\
\hline
\end{tabular}

\subsection{Results of regression models}

In order to determine the significance and relative importance of socio-demographic, lifestyle, and environmental beliefs variables in predicting general policy support, a linear regression analysis was performed with average policy support scores. Relatively few socio-demographic factors predicted respondents' overall strength of support for pro-environmental aviation policy (Table 4). Compared to non-flyers, those who fly at least once per year for business or leisure are less likely to be in favour of the surveyed policies $(\mathrm{p}<0.001)$. Strong pro-environmental beliefs are significant predictors of increased support $(\mathrm{p}<0.001)$, as are being in possession of a first degree and believing that non-governmental organisations (NGOs) have a responsibility for addressing climate change ( $\mathrm{ps}<0.05)$. Income, gender, age, and employment status were not significant predictors of overall degree of policy support.

Table 4. Multivariate regression analysis of overall policy support. (Significance: $*$ is $p<$ $0.05, * *$ is $p<0.01$, and $* * *$ is $p<0.001$.)

\begin{tabular}{|l|c|c|}
\hline & $\begin{array}{l}\text { Average } \\
\text { Policy } \\
\text { Support }\end{array}$ & $\begin{array}{l}\text { Average } \\
\text { Policy } \\
\text { Support }\end{array}$ \\
\hline Intercept & $1.71^{* * *}$ & $1.22^{* * *}$ \\
\hline Gender (male $=1)$ & 0.00 & 0.01 \\
\hline Age & -0.00 & -0.00 \\
\hline $1^{\text {st }}$ income quintile & 0.06 & 0.06 \\
\hline $2^{\text {nd }}$ income quintile & -0.02 & -0.02 \\
\hline $4^{\text {th }}$ income quintile & 0.02 & -0.00 \\
\hline $5^{\text {th }}$ income quintile & -0.03 & -0.02 \\
\hline First degree & $0.08^{* *}$ & $0.07^{*}$ \\
\hline
\end{tabular}




\begin{tabular}{|c|c|c|}
\hline Flyer & $-0.23^{* * *}$ & $-0.24^{* *}$ \\
\hline Student & -0.11 & -0.11 \\
\hline Retired & -0.05 & -0.06 \\
\hline Unemployed & -0.01 & 0.00 \\
\hline Pro-environmental beliefs & $0.53^{* * *}$ & $0.43^{* * *}$ \\
\hline \multicolumn{3}{|l|}{$\begin{array}{l}\text { Responsibility for climate } \\
\text { change }\end{array}$} \\
\hline Local government & & 0.04 \\
\hline National government & & 0.03 \\
\hline $\begin{array}{l}\text { International gov't } \\
\text { partnerships }\end{array}$ & & 0.03 \\
\hline Industry & & 0.00 \\
\hline Charities & & 0.01 \\
\hline Non-governmental orgs. & & $0.06 * *$ \\
\hline General public & & 0.04 \\
\hline Adjusted $r^{2}$ & 0.32 & 0.35 \\
\hline
\end{tabular}

To determine the significance and relative importance socio-demographic, lifestyle, and environmental beliefs variables in predicting support for specific policy measures, a series of linear regression models of policy-specific support scores was performed (Table 5). Consistent with the overall policy support analysis (Table 4), being a flyer and holding strong pro-environmental beliefs were each significantly predictive of level of support for most policies $(p s<0.05)$. (These variables were also consistently strong determinants of support in terms of effect size.) Possession of a first degree was a significant predictor of support for four policies, including as a strong, negative predictor of support for an aviation tax. In general, females and males support policies to an equal degree, though females report stronger support for regulating the airline industry whilst males report stronger support for public recognition schemes for pro-environmental behaviour and for providing information about the environmental impacts of air travel. As was the case with overall policy support, neither age nor employment variables had any significance in any specific policy analysis. Degree of belief in the responsibility of particular institutions for addressing climate change was a predictor of policy support for eleven of the fourteen policies under consideration. 
Table 5. Multivariate regression analyses of support for specific policy options. (Significance signifiers: $*$ is $p<0.05, * *$ is $p<0.01$, and $* * *$ is $p<0.001$.) From left to right, the policies are in descending order of average popularity.

\begin{tabular}{|c|c|c|c|c|c|c|c|c|c|c|c|c|c|c|}
\hline & $\begin{array}{l}\text { Public } \\
\text { transport }\end{array}$ & $\begin{array}{l}\text { Regulate } \\
\text { industry }\end{array}$ & $\begin{array}{l}\text { Limit } \\
\text { government } \\
\text { travel }\end{array}$ & $\begin{array}{l}\text { Incentives } \\
\text { for UK } \\
\text { holidays }\end{array}$ & $\begin{array}{l}\text { Provide } \\
\text { environmental } \\
\text { information }\end{array}$ & $\begin{array}{l}\text { Cross- } \\
\text { subsidization }\end{array}$ & $\begin{array}{l}\text { Mandatory } \\
\text { carbon } \\
\text { offsetting }\end{array}$ & $\begin{array}{l}\text { Public } \\
\text { recognition }\end{array}$ & $\begin{array}{l}\text { Frequent } \\
\text { flyer tax }\end{array}$ & $\begin{array}{l}\text { Personal } \\
\text { carbon } \\
\text { allowance }\end{array}$ & $\begin{array}{l}\text { Increase } \\
\text { aviation } \\
\text { tax }\end{array}$ & $\begin{array}{l}\text { Personal } \\
\text { carbon } \\
\text { trading } \\
\end{array}$ & $\begin{array}{l}\text { Limits on } \\
\text { number } \\
\text { of flights }\end{array}$ & $\begin{array}{l}\text { Sanction } \\
\text { on all- } \\
\text { inclusives }\end{array}$ \\
\hline Intercept & $1.63 * * *$ & $0.83^{* * *}$ & $1.95^{* * *}$ & $2.15^{* * * *}$ & $0.70^{* * *}$ & $1.07^{* * *}$ & $0.51^{* * *}$ & $1.18^{* * *}$ & $1.01^{* * *}$ & $0.82^{* * *}$ & $0.84 * * *$ & $1.59^{* * *}$ & $1.43^{* * *}$ & $1.34^{* * *}$ \\
\hline Gender (male $=1$ ) & 0.04 & $-0.09 * *$ & -0.06 & -0.04 & $0.09 *$ & 0.03 & 0.02 & $0.14^{* *}$ & -0.00 & 0.00 & 0.04 & -0.02 & -0.06 & 0.01 \\
\hline Age & -0.00 & -0.00 & -0.00 & -0.00 & -0.00 & -0.00 & -0.00 & 0.00 & -0.00 & -0.00 & -0.00 & -0.00 & -0.00 & 0.00 \\
\hline $1^{\text {st }}$ income quintile & 0.02 & -0.01 & 0.06 & -0.05 & 0.01 & 0.09 & $0.13^{*}$ & 0.09 & 0.07 & 0.08 & 0.08 & 0.09 & 0.07 & $0.17^{*}$ \\
\hline $2^{\text {nd }}$ income quintile & -0.04 & -0.04 & 0.01 & -0.11 & -0.03 & -0.04 & 0.02 & -0.02 & -0.00 & -0.02 & 0.03 & -0.09 & -0.01 & -0.01 \\
\hline $4^{\text {th }}$ income quintile & $0.13^{*}$ & 0.03 & 0.05 & $-0.14^{*}$ & $\begin{array}{l}-0.04 \\
\end{array}$ & 0.08 & 0.11 & -0.12 & -0.10 & -0.02 & 0.03 & 0.03 & $\begin{array}{l}-0.02 \\
\end{array}$ & -0.05 \\
\hline $5^{\text {th }}$ income quintile & 0.10 & -0.04 & 0.07 & -0.02 & -0.13 & -0.04 & 0.06 & -0.16 & -0.07 & -0.05 & 0.02 & -0.05 & -0.00 & 0.04 \\
\hline First degree & 0.06 & 0.00 & -0.00 & -0.06 & 0.07 & $0.21 * * *$ & 0.05 & 0.08 & $0.12^{*}$ & 0.08 & $0.16^{* * *}$ & 0.02 & 0.06 & $0.10^{*}$ \\
\hline Flyer & -0.05 & $-0.11 * *$ & $-0.11 *$ & $-0.15 * *$ & $\begin{array}{l}-0.12 * * \\
\end{array}$ & $-0.25 * * *$ & $-0.26 * * *$ & $-0.22 * * *$ & -0.55*** & $-0.17 * * *$ & $-0.57 * * *$ & -0.06 & -0.44*** & $-0.28 * * *$ \\
\hline Student & -0.03 & -0.06 & $\begin{array}{l}-0.31^{* *} \\
\end{array}$ & -0.04 & $-0.20^{*}$ & -0.07 & -0.03 & 0.04 & $-0.39 * *$ & -0.06 & -0.12 & -0.05 & -0.16 & $\begin{array}{l}-0.08 \\
\end{array}$ \\
\hline Retired & 0.09 & -0.04 & $0.24^{* * *}$ & $-0.22^{* * *}$ & $-0.14 * *$ & -0.01 & -0.01 & -0.20 & -0.05 & -0.12 & -0.04 & $-0.27^{* * *}$ & -0.02 & -0.03 \\
\hline Unemployed & 0.12 & 0.01 & 0.11 & -0.02 & $\begin{array}{l}-0.02 \\
\end{array}$ & -0.05 & -0.01 & -0.06 & -0.03 & -0.02 & -0.02 & -0.01 & 0.08 & -0.02 \\
\hline Pro-environmental beliefs & $0.26^{* * *}$ & $0.41^{* * *}$ & $0.18^{* * *}$ & $0.14 * * *$ & $0.54^{* * *}$ & $0.43^{* * *}$ & $0.59 * * *$ & $0.48^{* * *}$ & $0.58^{* * *}$ & $0.54^{* * *}$ & $0.58^{* * *}$ & $0.27^{* * *}$ & $0.47^{* * *}$ & $0.43^{* * *}$ \\
\hline \multicolumn{15}{|l|}{$\begin{array}{l}\text { Responsibility for climate } \\
\text { change }\end{array}$} \\
\hline Local government & -0.02 & 0.04 & 0.07 & 0.05 & 0.03 & 0.02 & 0.01 & $0.08^{*}$ & -0.02 & 0.07 & -0.02 & 0.05 & 0.06 & $0.10^{* *}$ \\
\hline National government & $0.13^{* *}$ & $0.09 *$ & -0.01 & 0.08 & 0.06 & 0.04 & 0.05 & 0.00 & 0.11 & -0.04 & 0.09 & -0.07 & -0.03 & -0.09 \\
\hline $\begin{array}{l}\text { International gov't } \\
\text { partnerships }\end{array}$ & 0.03 & $0.09 *$ & 0.11 & 0.09 & 0.03 & $0.11^{*}$ & 0.05 & -0.02 & 0.02 & 0.04 & -0.06 & 0.09 & -0.07 & -0.04 \\
\hline Industry & $0.14^{* * *}$ & $0.15^{* * *}$ & 0.07 & 0.04 & -0.03 & 0.01 & -0.02 & -0.08 & -0.04 & -0.05 & -0.05 & -0.03 & -0.03 & -0.03 \\
\hline Charities & -0.02 & $-0.05 *$ & $-0.09 * *$ & 0.01 & 0.01 & -0.01 & -0.02 & $0.10 * *$ & 0.01 & 0.03 & 0.03 & 0.05 & 0.02 & 0.03 \\
\hline $\begin{array}{l}\text { Non-governmental } \\
\text { orgs. }\end{array}$ & 0.00 & 0.04 & 0.06 & 0.01 & 0.04 & 0.03 & 0.06 & -0.01 & 0.06 & 0.07 & $0.10^{* *}$ & $0.10^{*}$ & $0.13^{* *}$ & $0.15^{* * *}$ \\
\hline General public & $0.07^{*}$ & $0.08 * *$ & $0.09 *$ & 0.04 & $0.17^{* * *}$ & 0.06 & $0.12^{* * *}$ & 0.05 & -0.01 & 0.04 & -0.00 & -0.04 & -0.06 & -0.09 \\
\hline Adjusted $r^{2}$ & 0.17 & 0.30 & 0.09 & 0.08 & 0.33 & 0.20 & 0.26 & 0.16 & 0.19 & 0.17 & 0.24 & 0.08 & 0.12 & 0.13 \\
\hline
\end{tabular}


There is not a consistent relationship between income and policy support. With nine of the fourteen policy options, there is no significant difference in predicted policy support across the five income quintiles. Higher income quintiles are associated with greater support for an aviation tax, mandatory carbon offsetting for flights, and public transportation services and associated with less support for providing environmental information about flights. Relative to middle-income earners, respondents in lower income quintiles voiced greater support for mandatory carbon offsetting and limits on cruises and all-inclusives.

\section{Discussion}

This work makes an original contribution by addressing a gap in the tourism and transportation literature through using quantitative methods to assess support for public policies designed to reduce aviation-based carbon emissions. Further, this large-scale survey of the British population provides policy makers with a gauge of public acceptability of a diverse set of policy options.

The mean policy support values (Table 2) suggest that there is greater public support for policies that create the greatest distance between the individual and the costs of the policies. That is, the most highly supported policies either direct benefits to the general public (e.g., developing public transportation or providing financial incentives) or impose hard costs on others, like the aviation industry or government officials. Conversely, the least popular options are hard policies that directly affect the individual, including increased taxes and limits on certain travel options. These results are consistent with past work examining support for climate-relevant policies, which revealed a general preference for less stringent means of achieving climate goals (Attari et al. 2016; Attari et al. 2009). These findings might also reflect a general aversion to policies that interfere in the marketplace, particularly given that the rank ordering of policies in Table 2 mirrors the hierarchy of tolerances that Cherry et al. (2012) identify, with subsidies rating greater support than taxes, which in turn had greater support than quantity control measures.

An important caveat for these findings is that the survey instrument tended to present one side of each policy choice. That is, several of the policy items were presented either in terms of upside or downside, but rarely both. For example, "develop public transport services in the UK and across Europe as an alternative to flying" highlights a benefit without making salient the potential (opportunity) cost of this policy. Conversely, "introduce a frequent flyer tax" threatens increased taxation without naming a potential, tangible benefit. Interestingly, the item on cross-subsidisation, which most clearly describes a cost and a benefit scores exactly in the middle of "develop public transport" and "increase aviation tax" (3.5 versus 4.0 and 3.0). This finding is consistent with the idea that pairing a push and pull measure will make the pull measure more palatable (Banister 2008).

Viewing air travel as a 'tragedy of the commons' (Higham et al. 2014; Shaw and Thomas 2006), such self-interested preference ranking is in keeping with Wilke's (1991) GEF hypothesis, which states that greed is the primary motivating force in social dilemmas. Past work has borne out the general GEF framework, not just in its original context of common-pool resources but for environmental policies, as well (e.g., Jakobsson et al. [2000]). In the current study, such selfinterested motives are evident in both the preference ranking of policy options (Table 2) and in the regression analyses of overall and policy-specific support (Tables 4 and 5). Flyers signalled significantly less support for most policies than did non-flyers, arguably because they are the population segment most likely to bear the costs, direct or otherwise, of pro-environmental aviation policies. 
Though there is evidence of a strong reflection of self-interest in these findings, it remains the case that there is solid support for policies that address the climate impacts of flying: only three policies were rated with below-neutral levels of support. Looking at policy support in aggregate, sociodemographic, including gender, income level, and employment status are not predictive of strength of policy support, though possession of a college degree corresponds to slightly higher levels of support. At the policy-specific level, socio-demographic variables could predict strength of support, though not in a consistent fashion or with large effect sizes. Stronger pro-environmental beliefs correspond to greater support for all fourteen policies considered, a finding consistent with past research (Attari et al. 2009; Eriksson et al. 2006).

The GEF hypothesis holds that greed is in part checked by a desire for equity of policy outcomes, that is, by a belief in fairness. The data reported in this paper most directly speak to defining fairness in terms of culpability, wherein the costs of a policy are distributed in proportion to individual responsibility for creating the problem. Evidence of favourability for this form of fairness can be seen at the aggregate and policy-specific levels.

Respondents indicated that all seven sectors examined are responsible for addressing climate change (Table 3), suggesting that the public holds multiple actors responsible for addressing climate change, albeit to varying degrees. Consistent with past research (e.g., Ryley et al. 2010), this survey finds that people attribute greater responsibility to industry and policymakers than to the general public. This wide attribution of responsibility to many parties might explain the positive support by respondents for a broad range of policy options: if many actors are responsible for aviation-based climate emissions, then multiple policies targeting different actors would be appropriate and fair. And, indeed, policies that would directly affect the public, industry, and government all received some degree of support.

Looking at specific policies, there are multiple instances where perceived sectoral responsibility for addressing climate change corresponds to greater policy support (Table 5). For example, belief in the responsibility of national government to address climate change is a significant predictor of support for the development of national public transportation options. Similarly, holding the aviation industry responsible for addressing climate change is a significant correlate of support for greater industry regulation, whilst a strong sense that the public should tackle climate change predicts support for providing individuals with environmental information and requiring mandatory carbon offsetting of the emissions from flying. More challenging to interpret is why the NGO variable should be the only significant sectoral predictor of support for the four least popular policy options and for overall policy support (Table 4). One potential explanation is that those people who view NGOs - a very minor sectoral player in terms of greenhouse gas emissions - as responsible for addressing climate change may hold strong opinions about the necessity of making every effort to address climate change. This sense of urgency may, in turn, drive support for the adoption of hard, personally impactful measures (such as the least popular among this study's set of fourteen) so long as they mitigate carbon emissions. As with past research, pull measures examined in this study were preferred to push measures, possibly because they are perceived to be more fair (Eriksson et al. 2008), less of an infringement on freedom (Eriksson et al. 2006), and more effective (Drews and van den Bergh 2015; Steg et al. 2006). Policy makers could emphasise the fairness of policies in order to garner more support for their proposals.

The amount of variance in policy support explained by the fourteen individual models displayed in Table 5 ranges from low to moderate, as indicated by the adjusted $r^{2}$ values. The incorporation of various factors might improve the explanatory power of these models. For example, the GEF hypothesis suggests a third factor that influences policy support: efficiency, or collective policy success. The greed that might lead individuals to resist personally costly policies could be allayed 
by a belief that the proposed policy will actually solve, and solve efficiently, the environmental problem it is designed to address. Level of support can be affected by knowledge about the effectiveness of proposed policies (O'Connor et al. 1998), and so including a measure of perceived policy efficiency could improve model fit as well as provide a more comprehensive testing of the GEF hypothesis within the context of environmental policy. Further, political beliefs and attitudes toward government have an influence on support for and response to environmental policies (Costa and Kahn 2013; Harrison et al. 1996; Konisky et al. 2008), as do levels of general social trust (Drews and van den Bergh 2015; Macias 2015; Pretty and Ward 2001). Future work to provide a quantitative basis for understanding aviation policy acceptance might draw on these general environmental policy findings. Looking at specific policies, a lack of familiarity with some of the proposed policy options may have created uncertainty among respondents. Policies that are likely fairly well known, like taxes, regulation, and providing information, tended to produce better-fit models than more esoteric policy approaches like personal carbon trading.

\section{Conclusion}

The aim of this paper was to provide a significant and original contribution through conducting a quantitative assessment of the acceptability of a broad range of aviation climate policy options. While socio-demographic factors were tested for effect on support for pro-environmental aviation policy the results show widespread uniformity of view on the various policy options presented, which is largely independent of income, gender, age, and employment status. Significant effect was seen for being a non-flyer, having strong pro-environmental beliefs and having a first degree, and believing that NGOs have a responsibility for addressing climate change.

The present findings support Higham et al.'s (2016) observation that UK citizens more strongly support policy approaches that put a financial burden on industry rather than individuals directly, and are supportive of taxing aviation fuel in order to subsidise rail. Higham et al. (2016) also stress a reluctance among the British to accept government regulation, such as taxation, that is simply passed down from industry to consumers; they emphasise that the airline industry must shoulder much of the economic burden of carbon taxes. This is quantitatively supported in the present study, where policy options wherein the primary costs became more distant to the average consumer were more popular. The most popular policies were those that would place the financial burden for a low-carbon transition squarely on industry and the public sector, while the policies that would impose limits on or increase the cost of flying for individuals garnered the least support. Policymakers pursuing the most publically palatable policies will still have to contend, however, with powerful aviation lobby groups that seek to protect their industry from regulation (cf. Gössling and Cohen 2014).

As a final point, this paper provides a quantitative evidence base to policy makers on what types of policies are most acceptable to the public for addressing aviation climate emissions. However, aviation policy cannot be negotiated at a national level only, and even regional efforts such as the European Emissions Trading Scheme has faced considerable resistance from American and Asian airlines. Indeed, a parallel can be suggested between the tragedy of the commons effect seen from respondents' in this survey, and the behaviour of countries to support their national aviation industries while externalising the associated climate emissions. Overcoming this dilemma, at both an individual and a national level, represents the future for any policy-focused solution.

\section{Acknowledgements}

We are grateful for the feedback this work received from Andrew Hares and for the comments of its two anonymous reviewers. 


\section{References}

Araghi, Y., Kroesen, M., Molin, E., \& Van Wee, B. (2016). Revealing heterogeneity in air travelers' responses to passenger-oriented environmental policies: A discrete-choice latent class model. International Journal of Sustainable Transportation, 10(9), 765-772. doi:10.1080/15568318.2016.1149645

Attari, S., Krantz, D., \& Weber, E. (2016). Energy conservation goals: What people adopt, what they recommend, and why. Judgment and Decision Making, 11(4), 342-351.

Attari, S. Z., Schoen, M., Davidson, C. I., DeKay, M. L., Bruine de Bruin, W., Dawes, R., \& Small, M. J. (2009). Preferences for change: Do individuals prefer voluntary actions, soft regulations, or hard regulations to decrease fossil fuel consumption? Ecological Economics, 68(6), 1701-1710. doi:10.1016/j.ecolecon.2008.10.007

Banister, D. (2008). The sustainable mobility paradigm. Transport Policy, 15(2), 73-80. doi:10.1016/j.tranpol.2007.10.005

Barr, S., Gilg, A., \& Shaw, G. (2011). Citizens, consumers and sustainability: (Re)Framing environmental practice in an age of climate change. Global Environmental Change, 21(4), 1224-1233. doi:10.1016/j.gloenvcha.2011.07.009

Becken, S., \& Mackey, B. (2017). What role for offsetting aviation greenhouse gas emissions in a deep-cut carbon world? Journal of Air Transport Management, 63, 71-83. doi:10.1016/j.jairtraman.2017.05.009

Bows, A., \& Anderson, K. L. (2007). Policy clash: Can projected aviation growth be reconciled with the UK Government's 60\% carbon-reduction target? Transport Policy, 14(2), 103110. doi:10.1016/j.tranpol.2006.10.002

Cames, M., Graichen, J., Siemons, A., \& Cook, V. (2015). Emission reduction targets for international aviation and shipping. Study for the ENVI Committee. Directorate-General for Internal Policies, European Parliament.

Capstick, S., Lorenzoni, I., Corner, A., \& Whitmarsh, L. (2014). Prospects for radical emissions reduction through behavior and lifestyle change. Carbon Management, 5(4), 429-445. doi:10.1080/17583004.2015.1020011

Cherry, T. L., Kallbekken, S., \& Kroll, S. (2012). The acceptability of efficiency-enhancing environmental taxes, subsidies and regulation: An experimental investigation. Environmental Science \& Policy, 16, 90-96. doi:10.1016/j.envsci.2011.11.007

Cohen, S. A., Higham, J., Gössling, S., Peeters, P., \& Eijgelaar, E. (2016). Finding effective pathways to sustainable mobility: bridging the science-policy gap. Journal of Sustainable Tourism, 24(3), 317-334. doi:10.1080/09669582.2015.1136637

Costa, D. L., \& Kahn, M. E. (2013). Energy Conservation "nudges" and Environmentalist Ideology: Evidence from a Randomized Residential Electricity Field Experiment. Journal of the European Economic Association, 11(3), 680-702. doi:10.1111/jeea.12011

de Winter, J. C. F., \& Dodou, D. (2010). Five-Point Likert Items: t Test versus Mann-WhitneyWilcoxon. Practical Assessment, Research \& Evaluation, 15(11). Accessed 17 July 2017

Department for Environment, Food and Rural Affairs. (2007). Attitudes and behaviour in relation to the environment. London: Department for Environment, Food and Rural Affairs.

Department for Environment, Food and Rural Affairs. (2009). Public attitudes and bebaviours towards the environment - tracker survey. London: Department for Environment, Food and Rural Affairs.

Drews, S., \& van den Bergh, J. C. J. M. (2015). What explains public support for climate policies? A review of empirical and experimental studies. Climate Policy, 16, 855-876. doi:10.1080/14693062.2015.1058240 
Eriksson, L., Friman, M., \& Gärling, T. (2008). Stated reasons for reducing work-commute by car. Transportation Research Part F: Traffic Psychology and Behaviour, 11(6), 427-433. doi:10.1016/j.trf.2008.04.001

Eriksson, L., Rice, J. M., \& Goodin, R. E. (2006). Temporal Aspects of Life Satisfaction. Social Indicators Research, 80(3), 511-533. doi:10.1007/s11205-006-0005-z

Field, A. (2013). Discovering statistics using IBM SPSS Statistics: and sex and drugs and rock " $n$ " roll (4th ed.). London: Sage.

Filimonau, V., \& Högström, M. (2017). The attitudes of UK tourists to the use of biofuels in civil aviation: An exploratory study. Journal of Air Transport Management, 63, 84-94. doi:10.1016/j.jairtraman.2017.06.002

Gössling, S., \& Cohen, S. (2014). Why sustainable transport policies will fail: EU climate policy in the light of transport taboos. Journal of Transport Geography, 39, 197-207. doi:10.1016/j.jtrangeo.2014.07.010

Gössling, S., Cohen, S. A., \& Hares, A. (2016). Inside the black box: EU policy officers' perspectives on transport and climate change mitigation. Journal of Transport Geography, 57, 83-93. doi:10.1016/j.jtrangeo.2016.10.002

Hanna, P., Kantenbacher, J., Cohen, S., \& Gössling, S. (2017). Role model advocacy for sustainable transport. Transportation Research Part D: Transport and Environment. doi:10.1016/j.trd.2017.07.028

Hares, A., Dickinson, J., \& Wilkes, K. (2010). Climate change and the air travel decisions of UK tourists. Journal of Transport Geography, 18(3), 466-473. doi:10.1016/j.jtrangeo.2009.06.018

Harrison, C. M., Burgess, J., \& Filius, P. (1996). Rationalizing environmental responsibilities: A comparison of lay publics in the UK and the Netherlands. Global Environmental Change, 6(3), 215-234. doi:10.1016/0959-3780(96)00016-7

Higham, J., Cohen, S., Cavaliere, C., Reis, A., \& Finkler, W. (2016). Climate change, tourist air travel and radical emissions reduction. Journal of Cleaner Production, 111, 336-347. doi:10.1016/j.jclepro.2014.10.100

Higham, J. E. S., \& Cohen, S. A. (2011). Canary in the coalmine: Norwegian attitudes towards climate change and extreme long-haul air travel to Aotearoa/New Zealand. Tourism Management, 32(1), 98-105. doi:10.1016/j.tourman.2010.04.005

Higham, J. E. S., Cohen, S. A., \& Cavaliere, C. T. (2014). Climate Change, Discretionary Air Travel, and the "Flyers' Dilemma". Journal of Travel Research, 53(4), 462-475. doi:10.1177/0047287513500393

HMRC. (n.d.). Percentile points from 1 to 99 for total income before and after tax - GOV.UK. https://www.gov.uk/government/statistics/percentile-points-from-1-to-99-for-totalincome-before-and-after-tax. Accessed 4 September 2017

International Energy Agency. (2009). Transport, Energy and CO2: Moving Towards Sustainability. Paris: Transport, Energy and CO2: Moving Towards Sustainability.

Jakobsson, C., Fujii, S., \& Gärling, T. (2000). Determinants of private car users' acceptance of road pricing. Transport Policy, 7(2), 153-158. doi:10.1016/S0967-070X(00)00005-6

Konisky, D. M., Milyo, J., \& Richardson, L. E. (2008). Environmental Policy Attitudes: Issues, Geographical Scale, and Political Trust*. Social Science Quarterly, 89(5), 1066-1085. doi:10.1111/j.1540-6237.2008.00574.x

Kroesen, M. (2013). Exploring people's viewpoints on air travel and climate change: understanding inconsistencies. Journal of Sustainable Tourism, 21(2), 271-290. doi:10.1080/09669582.2012.692686

Lumley, T., Diehr, P., Emerson, S., \& Chen, L. (2002). The Importance of the Normality Assumption in Large Public Health Data Sets. Annual Review of Public Health, 23(1), $151-$ 169. doi:10.1146/annurev.publhealth.23.100901.140546 
Macias, T. (2015). Risks, Trust, and Sacrifice: Social Structural Motivators for Environmental Change: Risks, Trust, and Sacrifice. Social Science Quarterly, 96(5), 1264-1276. doi:10.1111/ssqu.12201

McManners, P. J. (2016). Developing policy integrating sustainability: A case study into aviation. Environmental Science \& Policy, 57, 86-92. doi:10.1016/j.envsci.2015.11.016

Miller, G., Rathouse, K., Scarles, C., Holmes, K., \& Tribe, J. (2010). Public understanding of sustainable tourism. Annals of Tourism Research, 37(3), 627-645. doi:10.1016/j.annals.2009.12.002

O’Connor, R. E., Bord, R. J., \& Fisher, A. (1998). How information about likely accomplishments affects willingness to sacrifice to reduce global warming. Journal of Risk Research, 1(3), 197-207. doi:10.1080/136698798377123

Owen, B., Lee, D. S., \& Lim, L. (2010). Flying into the Future: Aviation Emissions Scenarios to 2050. Environmental Science \& Technology, 44(7), 2255-2260. doi:10.1021/es902530z

Peeters, P., Higham, J., Kutzner, D., Cohen, S., \& Gössling, S. (2016). Are technology myths stalling aviation climate policy? Transportation Research Part D: Transport and Environment, 44, 30-42. doi:10.1016/j.trd.2016.02.004

Pretty, J., \& Ward, H. (2001). Social Capital and the Environment. World Development, 29(2), 209227. doi:10.1016/S0305-750X(00)00098-X

Ryley, T., Davison, L., Bristow, A., \& Pridmore, A. (2010). Public Engagement on Aviation Taxes in the United Kingdom. International Journal of Sustainable Transportation, 4, 112-128. doi:10.1080/15568310802471735

Shaw, S., \& Thomas, C. (2006). Discussion Note: Social and Cultural Dimensions of Air Travel Demand: Hyper-Mobility in the UK? Journal of Sustainable Tourism, 14, 209-215. doi:10.1080/09669580608669053

Steg, L., Dreijerink, L., \& Abrahamse, W. (2006). Why are Energy Policies Acceptable and Effective? Environment and Behavior, 38(1), 92-111. doi:10.1177/0013916505278519

Wilke, H. A. M. (1991). Greed, Efficiency and Fairness in Resource Management Situations. European Review of Social Psychology, 2, 165-187. doi:10.1080/14792779143000051

\section{Appendix A}

\section{Environmental attitudes}

Who do you think is responsible for tackling the issue of climate change? ( $n b$ : Respondents were asked to rate the following items on a 5-point scale that ran from 'not at all responsible' to 'very responsible.')

1. Local government

2. National government

3. International government partnerships (e.g., climate change summits)

4. Industry

5. Charities

6. Non-government organisations

7. General Public

\section{Policy options}

Over the past ten years a range of policy initiatives related to holidays and flying have been proposed as ways to meet national and international environmental targets. What follows will 
describe a series of these proposed policy options and you are then asked to rate the extent to which you would support/reject such initiatives.

1. Provide explicit information on the environmental effects of each flight at the point of booking (e.g. tangible information on $\mathrm{CO} 2$ emissions for each flight in a similar way to energy saving light bulbs or a traffic light system similar to that for salt and fat on food packaging)

2. Increase aviation tax to account for the environmental impacts of flying

3. Introduce a frequent flyer tax

4. Make carbon offsetting a statuary requirement on all flight bookings

5. Introduce cross-subsidization (e.g. money from taxing air travel invested into public transport provision and price)

6. Introduce a personal carbon allowance scheme in which an individual has an annual carbon limit for all of their personal (e.g. non-work related) lifestyle activities

7. Allow for the trading (buying and selling) of an individual's carbon allowance should they not reach the annual limit or require additional carbon allowance

8. Regulate aviation industry to ensure reinvestment in the environment (e.g. \% of profit has to be invested into green initiatives)

9. Provide financial incentives (such as holiday subsidies) for UK based holidays

10. Impose sanctions (e.g. restrict the number/ban) on cruise and all inclusive holidays

11. Develop public transport services in the UK and across Europe to offer rail transport as a viable alternative to flying (e.g. High-speed Rail; interlinked European system reducing changes; reduced prices)

12. Introduce a public recognition scheme in which individuals are publicly acknowledged for their pro-environmental behaviours (e.g. stopping long-haul flights or frequent flying)

13. Impose sanctions on international travel from government officials to international meetings insisting on the use of video conferencing

14. Impose limits on the number of flights an individual can make each year 